\title{
The tibial fractures fixation system deformation characteristics
}

\author{
M.S. Shidlovskiy ${ }^{1} \bullet$ M.M. Dyman ${ }^{1} \bullet$ T.M. Omelchenko ${ }^{2}$ \\ 1 - Igor Sikorsky Kyiv Polytechnic Institute, Kyiv, Ukraine; \\ 2 - National Medical University of A.A. Bohomoltsia, Kyiv, Ukraine
}

Received: 04 September 2018 / Accepted: 15 November 2018

\begin{abstract}
The characteristics of stiffness are studied and the fixation means allowable load at fractures of the distal epimetazh of the tibia is calculated. The processes of a fracture points mutual displacements development under the influence of long-term cyclic loads are studied. Metal osteosynthesis was performed using various types of medial and lateral plates with angular stability and blocked plates for fixing fractures in the distal epimetazh of the tibia. The tests are conducted under the influence of actual physiological loads of compression, bending and torsion, including cyclic loading modes.
\end{abstract}

Keywords: osteosynthesis, tibia, occipital plates, stiffness of fracture fixation, fracture fixation strength, fracture fixation stability.

Introduction. The tibia fractures with displacement of fragments belong to complex fractures that lead to longterm disability or even total disability. Metaphyseal and diaphyseal shin fractures takes up to $11-13 \%$ of all fractures. Treatment of such fractures remains one of the important problems of traumatology [1-6].

The tibia is the main supporting bone, which integrity basically depends on the function of the shin. Therefore, the fixation of fractures by standard and new plates, in addition to clinical indices, must have certain mechanical characteristics, in particular, sufficient rigidity and stability in long-term treatment, which can be accompanied by cyclic loads.

Purpose of the research. Today, there is no single point of view regarding the shape and size of the plates for fixing complex fractures of the tibia, therefore, in order to determine the optimal configuration of the plates, it is necessary to compare the rigidity of fixing the fragments using various fixatives. That is why it is necessary to develop a technique for conducting a full-scale experiment, to determine and compare the mechanical characteristics of the "bone-fracturefixing plate" system under the influence of external loads. For practical use of the results, it is advised to carry out experiments with the most physiological loads accompanying human walking (compression, bending and torsion).

Objects and methods of testing. As an object of the tests, uninjured in-situ tibia were used, selected and conserved according to the procedure [7]. Before the tests, direct transverse fractures at the level of the distal bone epimetaphysis were simulated on all tibia speciments [8]. Fractures were modeled by transverse osteotomy by an oscillatory saw and fixed by metallosteosynthesis using various plate variants (Figure 1, Table 1).

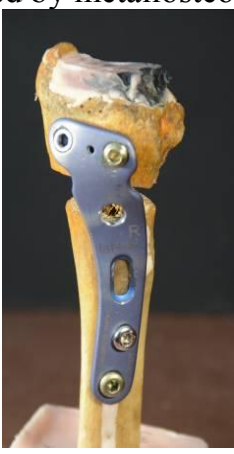

$a$

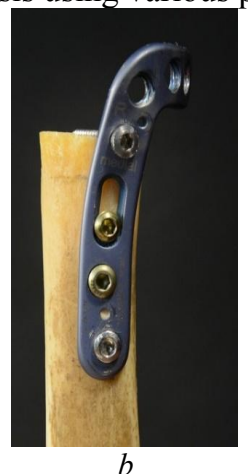

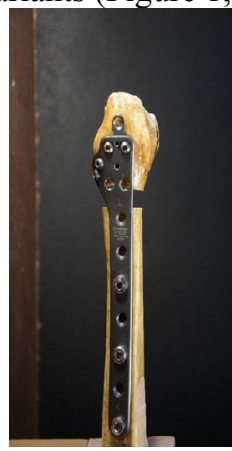

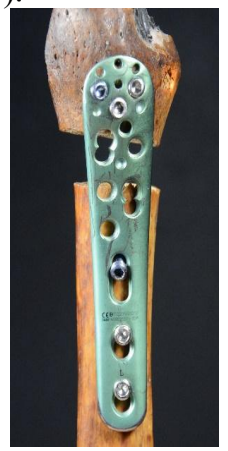

$d$

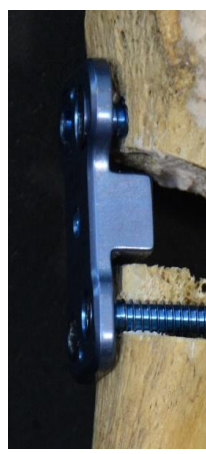

Fig. 1. Method of fixing fractures: a - lateral plate with angular stability "1L", b - medial L-shaped plate "1M", c - medial plate with angular stability "2M", $d$ - medial blocking plate "3M", e - X-shaped medial blocked plate for open correction of osteotomy "4M" 
Design features of plates $L$ - length, $H$ - thickness, $b$ - width

\begin{tabular}{|l|c|}
\hline \multicolumn{1}{|c|}{$\begin{array}{c}\text { Method of fixing fractures and } \\
\text { plate construction }\end{array}$} & Dimensions and number of screws \\
\hline Lateral blocked distal plate with angular stability - "1L" (plate with wide part) & $\begin{array}{c}\mathrm{L}=87 \mathrm{~mm}, \mathrm{H}=3 \mathrm{~mm} \\
\mathrm{~b}=17 \mathrm{~m}, 4 \mathrm{screw}\end{array}$ \\
\hline Medial distal L-shaped plate with angular stability - "1M" & $\begin{array}{c}\mathrm{L}=80 \mathrm{~mm}, \mathrm{H}=3 \mathrm{~mm} \\
\mathrm{~b}=15 \mathrm{~mm}, 6 \mathrm{screws}\end{array}$ \\
\hline Medial distal plate with angular stability - "2M" (straight plate) & $\begin{array}{c}\mathrm{L}=136 \mathrm{~mm}, \mathrm{H}=3 \mathrm{~mm} \\
\mathrm{~b}=14 \mathrm{~mm}, 7 \mathrm{screws}\end{array}$ \\
\hline The medial plate is blocked - "3M" (straight plate) & $\begin{array}{c}\mathrm{L}=91 \mathrm{~mm}, \mathrm{H}=3 \mathrm{~mm} \\
\mathrm{~b}=19 \mathrm{~mm}, 6 \mathrm{screws}\end{array}$ \\
\hline $\begin{array}{l}\text { Medial plate blocked for open correction osteotomy - "4M" (X-shaped plate with } \\
\text { reinforced intermediate part)) }\end{array}$ & $\begin{array}{c}\mathrm{L}=42 \mathrm{~mm}, \mathrm{H}=3 \mathrm{~mm} \\
\mathrm{~b}=22 \mathrm{~mm}, 4 \mathrm{screws}\end{array}$ \\
\hline
\end{tabular}

To fix the specimens up to the working table of the testing machine, plastic support heads were used (Figure 2a), which was made individually for each bone. The middle parts of the bones near the fixing plates were filled with special medical plastic (acrylic group composition of rapid cold approval [7]) and heads in the form of parallelepipeds were formed.

The main functions of fixing the supporting head is to minimize additional deformations of the specimens arising at the point of contact of the bone with the nodes of the test equipment and creating conditions for loading the bones in the given direction.
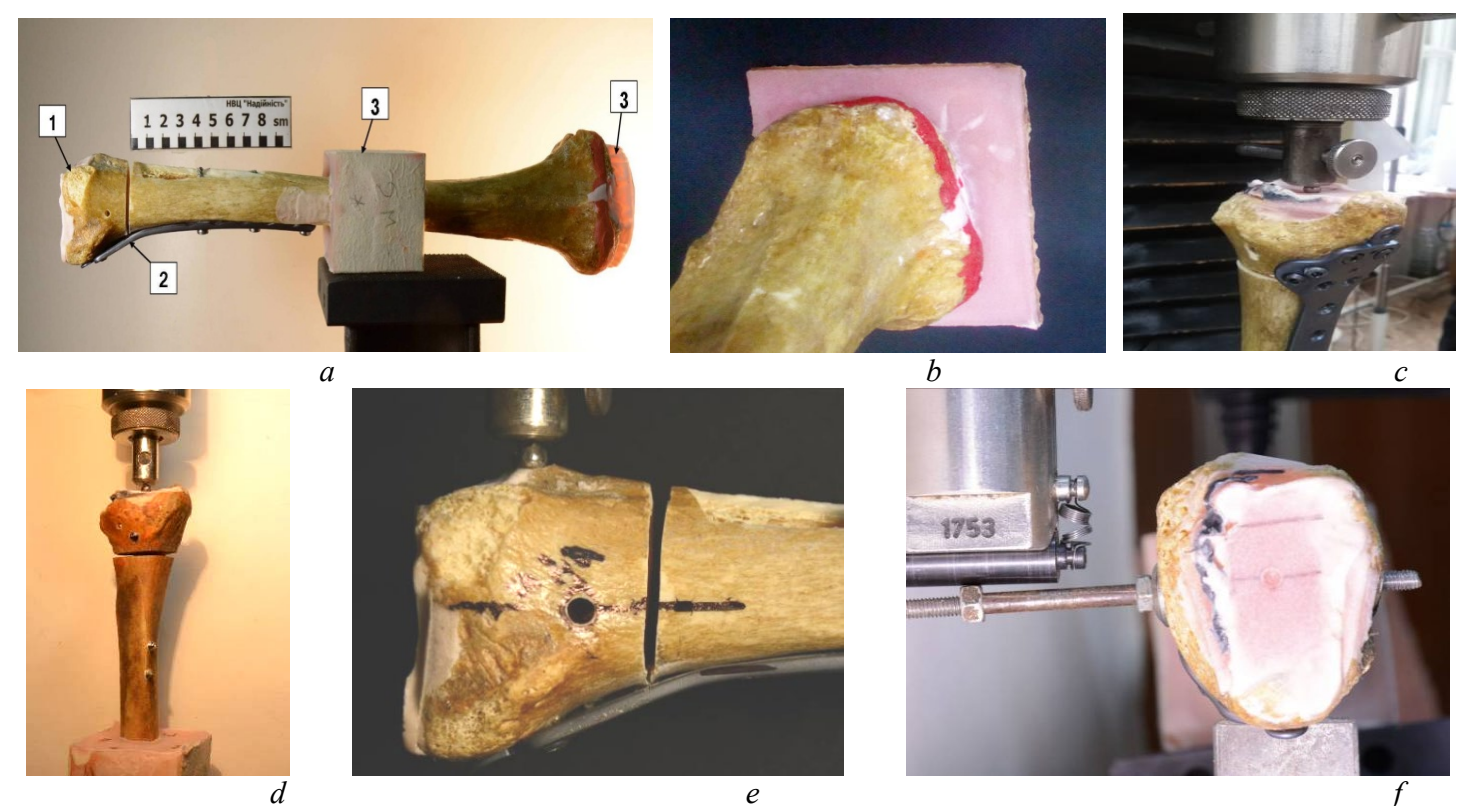

Fig. 2. Preparation and carrying out of tests: $a$ - tibia (1) with plate (2) and supporting head for bend and torsion tests (3); $b$ - plastic support for compression testing; $c$ - the place of contact of the rod with the plastic layer; $d$ - compression test; $e$ - bending test; $\mathrm{f}$ - torsion test

The lower support (Fig. 2b) is formed in the shape of a rectangular parallelepiped $10 \mathrm{~mm}$ thick with sides 80-90 $\mathrm{mm}$. Such dimensions of the sides ensure the location of the epiphyses within the area of the support.

Plastic heads with bones fixed inside were attached to the working table of the test setup with clamps. Efforts to the specimen were passed through a steel rod fixed to the dynamometer (Figure 2c).

To prevent the appearance of additional deformations at the point of contact of the rod with the distal epiphysis of the tibia, a plastic layer 3-5 mm thick was placed between the core and the bone (Fig. 2c).

Specimens were attached to the working table of the testing machines, loaded by means of grinding, bending and torsion (Fig. $2 \mathrm{~d}-2 \mathrm{e}$ ). The attempts were measured by dynamometer, the signal from which enters the microprocessor of the testing machine with an accuracy of $\pm 0.1 \mathrm{~N}$.

Loads, that acts on the specimen while the working table is lifted during stitching and driving (Fig. 2d, 2d), are applied using a steel ball with a diameter of $6 \mathrm{~mm}$. The ball was placed in the recess on the surface of the plastic layer 
applied to the bone (Fig. 2c). Torsional moment was applied through a steel rod with a diameter of $5 \mathrm{~mm}$, which was fixed to the epiphysis of the bone (Figure 2e).

The strain rate of the specimen was $2.5 \mathrm{~mm} / \mathrm{min}$ for compression, bending and torsion tests. Specimens loading was carried out within the linear relationship between force and displacement, and also until complete destruction of the "bone-plate" system under compression.

Coordinate axes, fracture points and point displacements labelling is determined by the method proposed in [7,9]. With the example of tibia with a fracture, fixed plate $2 \mathrm{M}$, the directions of the coordinate axes relative to the anatomical directions of the bone are shown (Fig. 3).

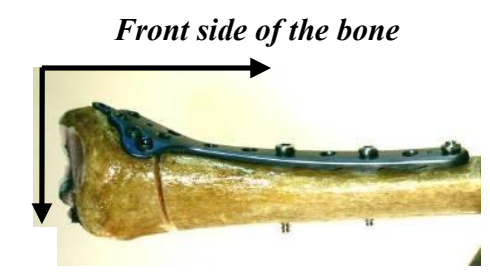

Back side of the bone

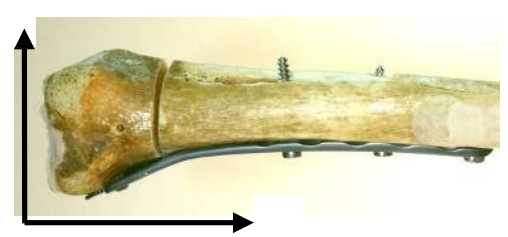

Medial side of the bone

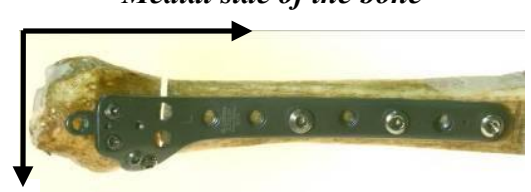

Lateral side of the bone

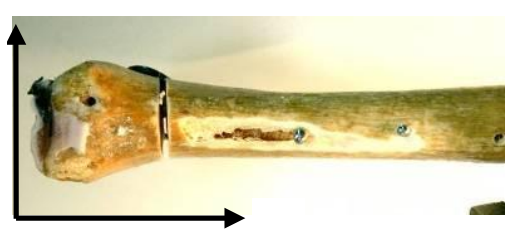

Fig. 3. Types of the sides of the bone and the direction of the coordinate axes relative to the fracture

Movements arising in fractures under the action of one-time loads were written by recording deformation diagrams and by the method of sequential photographing of the specimen with a digital camera. With the second way to measure displacements at identical distances from the specimens a digital camera was placed. The fracture site of tibia was photographed in the initial state (with a preliminary load of 5-10 N) and under the load of a predetermined value.

Photographic survey during the loading of specimens was carried out at intervals of $0.2 \mathrm{~s}$. The image was digitally processed, and mutual movements of various fracture points were determined. Further processing of photographs and determination of mutual displacements of fracture points under load was carried out according to the procedure described in [7, 10].

The test systems "tibia-plate" were subjected to loading by forces P1, P2, P3 (Figure 4). The points of application of loads were at distances e1, e2, e3 from the plates (Table 2).

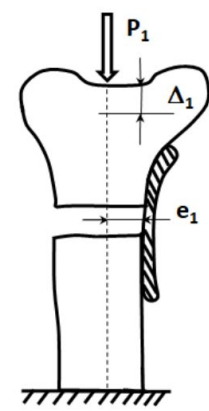

$a$

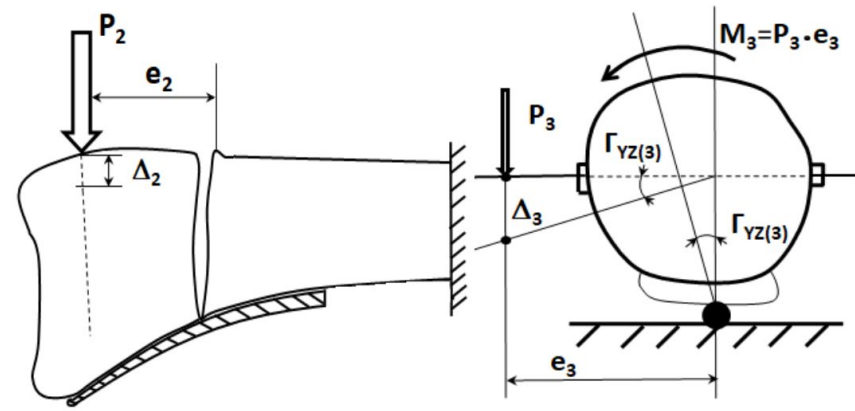

$b$ $c$

Fig. 4. Scheme of the load of the system "tibia with a fracture-plate" under compression (a), bending (b) and torsion (c)

Location of the point of application of loads relative to fixing plates (fig.4)

\begin{tabular}{|c|c|c|c|}
\hline Type of plate & $\mathrm{e}_{1}$ & $\mathrm{e}_{2}$ & $\mathrm{e}_{3}$ \\
\hline $1 \mathrm{~L}$ & 25.3 & 18.3 & 63.2 \\
\hline $1 \mathrm{M}$ & 15.0 & 21.6 & 46.1 \\
\hline $2 \mathrm{M}$ & 11.0 & 21.5 & 59.5 \\
\hline $3 \mathrm{M}$ & 17.5 & 20.6 & 56.9 \\
\hline $4 \mathrm{M}$ & 21.1 & 35.8 & 49.8 \\
\hline
\end{tabular}


According to the obtained deformation diagrams of the specimens after their tests according to the schemes shown in Fig. 4, the following indicators were determined:

$\mathrm{P}_{1}$ - loads that cause the displacement $\Delta_{1}$ of the load application point under compression (Figure 4a)

$\boldsymbol{\delta}_{\mathbf{1}}=\Delta_{\mathbf{1}} / \mathbf{P}_{\mathbf{1}}$ - the displacement of the points of application of the load with respect to the load is shown;

$\mathbf{M}_{1}=\mathbf{P}_{\mathbf{1}} \cdot \mathbf{e}_{\mathbf{1}}$ - moments of forces acting on the system during compression;

$\overline{\boldsymbol{\delta}}_{1}=\Delta_{1} / \mathbf{M}_{1}$ - the displacement point of the load application is shown relative to the bending moment;

The following symbols for absolute and adjusted linear displacements are adopted in the tables and in the figures:

$\Lambda_{\mathrm{X}(1)}$ and $\Lambda_{\mathrm{Z}(1)}$ are the projections of the mutual displacements of fracture points most distant from the plate on the $\mathrm{X}$ and $\mathrm{Z}$ axis;

$\Lambda_{(1)}=\sqrt{\left(\Lambda_{\mathrm{X}(1)}\right)^{2}+\left(\Lambda_{\mathrm{Z}(\mathbf{1})}\right)^{2}}$ - complete mutual displacement of the indicated points.

On the linear sections of the displacement diagrams, the displacement of fracture points under the action of the compressive load $\mathrm{P} 1$ is given:

$\lambda_{\mathbf{x}(1)}=\left|\Lambda_{\mathbf{x}(1)} / \mathbf{P}_{1}\right| \mathbf{T a} \lambda_{\mathbf{Z}_{(1)}}=\left|\Lambda_{\mathbf{z}_{(1)}} / \mathbf{P}_{\mathbf{1}}\right|$ - Movements of fracture points, most distant from the plate, in the longitudinal and transverse directions, respectively;

$\lambda_{(1)}=\sqrt{\left(\lambda_{\mathbf{X}(1)}\right)^{2}+\left(\lambda_{\mathrm{Z}(\mathbf{1})}\right)^{2}}$ - the complete displacement of the indicated points is given.

To determine the angular deformations of fractures during compression, the value of linear displacements of fracture points was used. The reciprocal angle of rotation of the fracture parts was determined from the values of the linear displacements of the opposite fracture points $\Lambda^{\mathrm{M}} \mathrm{X}_{(1)}$ and $\Lambda_{\mathrm{X}(1)}^{\mathrm{L}}$ in the $\mathrm{X}$ direction and the distance between them $\mathrm{S}_{\mathrm{ML}}$ :

$$
\Gamma_{\mathbf{X Z}(1)}=\operatorname{arctg}\left(\left|\Lambda^{\mathbf{M}_{(1)}}-\Lambda^{\mathrm{L}} \mathbf{X}(1)\right| / \mathbf{S}_{\mathrm{ML}}\right) .
$$

The given angle of rotation as the absolute angle, referred to the load:

$$
\gamma_{\mathrm{XZ}(1)}=\Gamma_{\mathrm{XZ}(1)} / \mathbf{P}_{1}
$$

or referred to the moment of force:

$$
\bar{\gamma}_{\mathrm{XZ}(1)}=\Gamma_{\mathrm{XZ}(1)} / \mathrm{M}_{1}
$$

Calculation of permissible loads. We accept permissible mutual displacement of the adjacent points of the fracture $[\Lambda]=1 \mathrm{~mm}[11,12]$. The rigidity condition and the permissible axial load under the action of the longitudinal force $\mathrm{P}_{1}$ only:

$$
\Lambda_{\text {MAX (1) }}=\lambda_{(1)} \cdot P_{1} \leq[\Lambda], P_{\text {allowable (1) }}=[\Lambda] / \lambda_{(1)}
$$

where $\Lambda_{\operatorname{MAX}(1)}$ the maximum mutual displacement in the fracture (mainly in the region farthest from the plate);

$\mathrm{P}_{\text {allowable (1) }}$ - is an allowable axial force, does not yet lead to an inadmissible misalignment.

We accept the permissible mutual angle of rotation of fracture parts $[\Gamma]=3^{0}[11,12]$. The rigidity condition for the maximum mutual angle of rotation of fracture parts and the permissible axial load under the action of the longitudinal force $\mathrm{P}_{1}$ only:

$$
\Gamma_{\text {MAX (1) }}=\gamma_{\mathrm{XZ}(1)} \cdot \mathbf{P}_{1} \leq[\Gamma], \mathbf{P}_{\text {allowable (1) }}=[\Gamma] / \gamma_{\mathrm{XZ}(1)}
$$

where $\Gamma_{\mathrm{MAX}(1)}$ the maximum mutual angle of rotation of fracture parts;

$\mathrm{P}_{\text {allowable (1) }}$ - is an allowable axial force, does not yet lead to the appearance of an unacceptable angle of fracture.

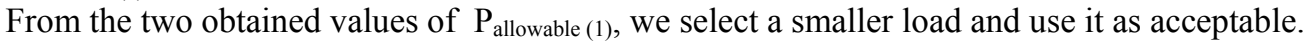

The calculation of the deformation characteristics (linear displacements and angles of rotation) of the osteosynthesis systems studied, as well as the determination of the allowable loads for bending and torsion, were carried out in a similar way.

In future, all the characteristics relating to the action of the bending moment on the force $\mathrm{P}_{2}$ (Figure $4 \mathrm{~b}$ ) are denoted by index 2. The characteristics relating to the action of the torque from the force $\mathrm{P}_{3}$ (Figure $4 \mathrm{c}$ ) are indicated by the index 3 .

Test results for short-term loads. It is of practical interest to compare the results of measuring the total deformation of the system "tibia with a fracture-plate" with displacements of points in the fracture region. Analysis of the results showed that for identical loads the displacement of points distant from the fixing plate significantly exceeds the displacement of the point of application of the system load (Fig. 4a). Thus, when the plate 1L is fixed, the total displacement $\lambda_{(1)}$ is $1.2 \ldots 1.3$ times larger than the displacement $\delta_{1}$, and when fixed with plates $1 \mathrm{M}, 2 \mathrm{M}$ and $3 \mathrm{M}-1.9 \ldots$ 2.3. The biggest difference between these indicators (in 2.8 ... 3.0 times) is noted for the $4 \mathrm{M}$ plate.

The performed comparisons show that when estimating the deformation properties of osteosynthesis systems it is not enough to use only general deformations of the "bone-fixation" system as a whole, but it is necessary to take into account the mutual displacements of the individual, most dangerous points of the fracture region. Such points for the investigated systems with one-sided fixation by plates are the points furthest from the plate. 
The method of estimating deformation reliability by measuring the displacement of only the point of application of the load, which is used in most studies of osteosynthesis systems, is insufficient. Therefore, in the analysis of the deformation reliability of these systems and in determining the permissible loads, only distant points are considered.

The deformation diagrams recorded in the coordinates "load - displacement of the load point" can be used, for example, to determine the loads corresponding to the boundaries of linear sections and the maximum load corresponding to the complete destruction of the system.

In Table. 3 shows the values of the above displacements of fracture points during compression and bending.

The displacement $(\mathrm{mm} / \mathrm{N})$ of fracture points in compression and bending

Table 3

\begin{tabular}{|c|c|c|c|c|}
\hline \multirow{2}{*}{ Load } & $\begin{array}{c}\text { Type of } \\
\text { plate }\end{array}$ & $\begin{array}{c}\text { Movement in the } \\
\text { longitudinal } \\
\text { direction } \boldsymbol{\lambda}_{\mathbf{x}(\mathbf{1})} \oplus \mathbf{1 0}^{\mathbf{3}}\end{array}$ & $\begin{array}{c}\text { Moving in the transverse } \\
\text { direction } \boldsymbol{\lambda}_{\mathbf{Z}(\mathbf{1})} \oplus \mathbf{1 0}^{\mathbf{3}}\end{array}$ & $\begin{array}{c}\text { Full displacement } \boldsymbol{\lambda}_{\mathbf{( 1 )}} \oplus \\
\mathbf{1 0}^{\mathbf{3}}\end{array}$ \\
\hline \multirow{4}{*}{$\begin{array}{c}\text { Compress } \\
\text { ion by } \\
\text { force } \mathbf{P}_{\mathbf{1}}\end{array}$} & $\mathbf{1 L}$ & $19.4 \pm 1.27$ & $1.25 \pm 0.10$ & $19.4 \pm 1.27$ \\
\cline { 2 - 5 } & $\mathbf{1 M}$ & $5.94 \pm 0.29$ & $0.87 \pm 0.06$ & $6.00 \pm 0.30$ \\
\cline { 2 - 5 } & $\mathbf{2 M}$ & $8.07 \pm 0.43$ & $1.16 \pm 0.09$ & $8.15 \pm 0.44$ \\
\hline \multirow{4}{*}{$\begin{array}{c}\text { Fold by } \\
\text { force } \mathbf{P}_{\mathbf{2}}\end{array}$} & $\mathbf{3 M}$ & $12.3 \pm 0.62$ & $2.36 \pm 0.11$ & $12.5 \pm 0.63$ \\
\cline { 2 - 5 } & $\mathbf{4 M}$ & $4.88 \pm 0.25$ & $0.50 \pm 0.02$ & $4.91 \pm 0.25$ \\
\cline { 2 - 5 } & $\mathbf{1 M}$ & $9.90 \pm 0.37$ & $33.0 \pm 0.48$ & $34.4 \pm 0.61$ \\
\cline { 2 - 5 } & $\mathbf{3 M}$ & $5.62 \pm 0.25$ & $6.60 \pm 0.36$ & $8.67 \pm 0.44$ \\
\cline { 2 - 5 } & $\mathbf{4 M}$ & $9.90 \pm 0.43$ & $4.40 \pm 0.19$ & $10.8 \pm 0.47$ \\
\hline
\end{tabular}

The data of Table. 3 shows that, both in compression and in flexion in fractures fixed by the investigated plates, the displacement occurs not only in the direction of application of the load, but also in transverse directions.

When compressing, the longitudinal movements in the direction of the load exceed the transverse displacement in 5.2 (plate $3 \mathrm{M}$ ) ... 15.5 (plate $1 \mathrm{~L}$ ) times. When bending, the ratio of longitudinal and transverse displacements is not singlevalued. In the fracture fixed by the plate $1 \mathrm{~L}$ the lateral displacements prevail (3.3 times as compared with the longitudinal displacement), and when fixed by the 3M plate - longitudinal (2.6 times compared with the transverse).

All this testifies that in estimating the maximum total displacements in the region of fractures fixed by such plates, it is necessary to take into account all the components of displacements, and not just the movement in the direction of the external loading-tanning action. It is necessary to analyze the spatial displacements of fracture points. In the future, when analyzing the patterns of deformation of the osteosynthesis systems studied, only the complete displacements of fracture points are taken into account.

Obviously, the biggest linear displacements are observed at the points of fracture, most remote from the junction with the plates, what is confirmed by photographs. Therefore, in the further analysis of the results, we limit ourselves to these fracture points (medial point for plate $1 \mathrm{~L}$ and lateral points for the remaining plates).

As can be seen from Table. 3, the deformation characteristics of the systems studied depend substantially on the type of plates and on the type of load. Thus, the complete movements in the fracture connected by the plate $1 \mathrm{~L}$ are greater than the displacement in the fracture with the $4 \mathrm{M}$ plate in 4 (compression) - 4.5 (bending) times.

In Fig. 5 shows comparison of linear and angular displacement in fractures joined by different types of plates.

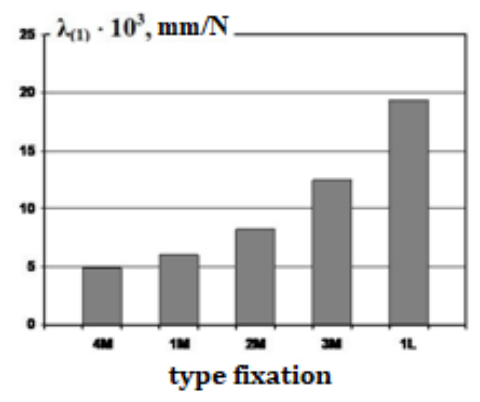

$a$

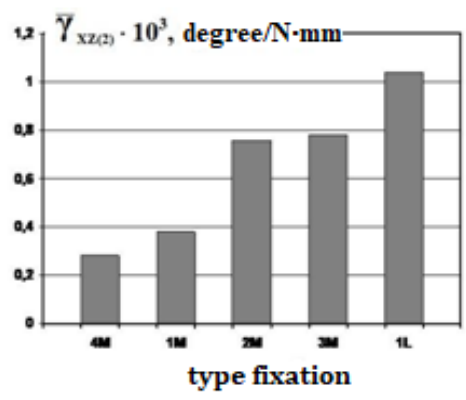

$b$

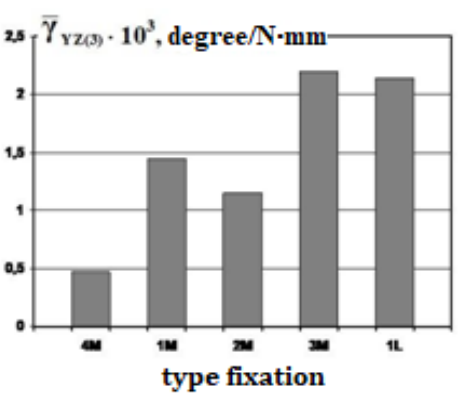

$c$

Fig. 5. Comparison of the reduced linear $(a)$ and angular $(b, c)$ displacements of fracture points fixed by different types of plates, under compression $(a)$, bending $(b)$ and torsion $(c)$ 
Tests showed that the smallest movements with all kinds of crustal-chest load arise in fractures connected by a plate of type $4 \mathrm{M}$, and the biggest in fractures connected by a plate of $1 \mathrm{~L}$. In bending, the connection of the fracture with the $4 \mathrm{M}$ plate is also the smallest total linear displacement compared with the rest of the plates (Table 3)

Table. 4 shows the permissible loads that do not lead to the occurrence of linear displacements, greater than $1 \mathrm{~mm}$, and the angles of mutual rotation of the fracture time, exceeding $3^{\circ}$. These data are reflected in the form of comparative diagrams in Fig. 6, on which only the minimum of two admissible loading-handles, calculated by linear displacement and the angle of rotation, are represented.

Table 4

Permissible loads calculated by the maximum permissible displacement $[\Lambda]=1 \mathrm{~mm}$ and the maximum permissible mutual angle of rotation of fracture parts $[\Gamma]=3^{0}$

\begin{tabular}{|c|c|c|c|c|c|c|}
\hline \multirow{2}{*}{$\begin{array}{c}\text { Type of } \\
\text { plate }\end{array}$} & \multicolumn{3}{|c|}{ Calculation of $[\mathbf{\Lambda}]=\mathbf{1}_{\mathbf{M M}}$} & \multicolumn{3}{c|}{ Calculation of $[\boldsymbol{\Gamma}]=\mathbf{3}^{\mathbf{0}}$} \\
\cline { 2 - 7 } & $\mathbf{P}_{1}$ allowed & $\mathbf{P}_{\mathbf{2}}$ allowed & $\mathbf{P}_{\mathbf{3} \text { allowed }}$ & $\mathbf{P}_{1 \text { allowed }}$ & $\mathbf{P}_{2}$ allowed & $\mathbf{P}_{3}$ allowed \\
\hline $\mathbf{1 L}$ & 51.5 & 29.1 & 6.02 & 111.9 & 157.6 & 9.38 \\
\hline $\mathbf{1 M}$ & 166.7 & 115.3 & 6.66 & 541.5 & 368.0 & 13.79 \\
\hline $\mathbf{2 M}$ & 122.6 & 92.4 & 6.99 & 361.9 & 184.2 & 12.74 \\
\hline $\mathbf{3 M}$ & 80.1 & 105.2 & 6.01 & 219.9 & 187.5 & 9.95 \\
\hline $\mathbf{4 M}$ & 203.7 & 130.2 & 20.88 & 488.6 & 294.4 & 41.67 \\
\hline
\end{tabular}

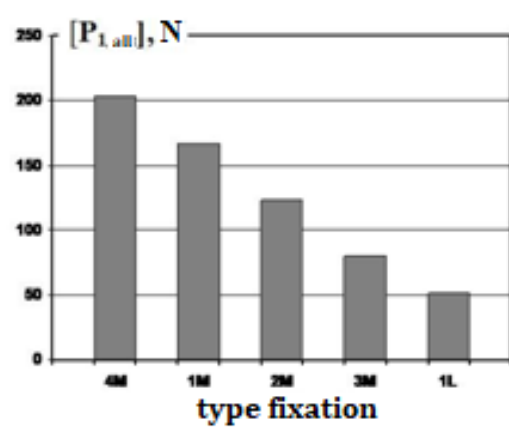

$a$

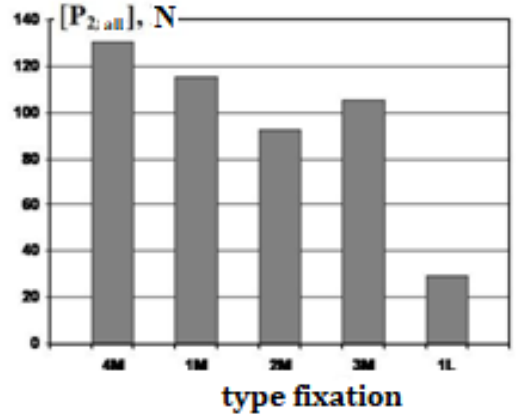

$b$

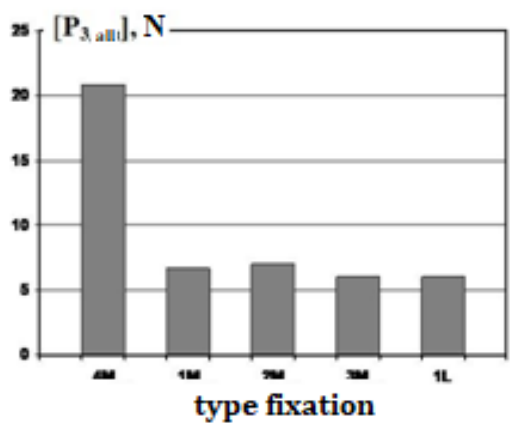

$c$

Fig. 6. Allowable loads, do not cause unacceptable linear movements and angles of rotation of fracture parts during compression ( $a)$, bending $(b)$ and torsion $(c)$

The values of the distances from the line of action of the forces to the fracture (eccentricities $\mathrm{e}_{1}$ and $\mathrm{e}_{2}$ ), given in Table 1, were used in calculating the values of the permissible $P_{\text {allowed (1) }}$ and $P_{\text {allowed (2) }}$ forces. 2. Calculations of the permissible loads of $\mathrm{P}_{\text {allowed (3) }}$ were carried out under the condition that this force acts at a distance $\mathrm{e}_{3 \Phi}=150 \mathrm{~mm}$ from the longitudinal axis of the tibia (lateral load on the distal region of the 1st metatarsal bone).

As it can be seen from Fig. 6, the largest values of the admissible forces correspond to the osteosynthesis systems with a 4M plate both in compression and in bending and torsion. This is sufficiently satisfactorily correlated with the values of the destructive loads determined in the compression test. The forces leading to complete destruction of the fixation by the $4 \mathrm{M}$ plate lie in the range $750 \ldots 767 \mathrm{~N}$ (the greatest load). The least destructive loads $(150 \ldots 180 \mathrm{~N})$ are noted for the fixation systems with plates $1 \mathrm{~L}$ and $1 \mathrm{M}$. Similar relationships are established for the boundaries of the linear sections of the deformation diagrams $(740 \ldots 750 \mathrm{~N}$ for fixing the $4 \mathrm{M}$ plate and $130 \ldots 140 \mathrm{~N}$ for $1 \mathrm{~L}$ and $1 \mathrm{M})$

Test results for cyclic loads. During walking, the lower limbs of person are subjected to multiple cyclic loads. Under the influence of these loads, deformations occur which do not disappear after unloading the specimen. The practice of experimental studies shows that residual ("delayed") deformations during cyclic loading of limbs with osteosynthesis systems may in some cases exceed strains that arise during a quick single loading, and this fact should be taken into account when evaluating the reliability of fixation of fractures.

The experiments carried out under the cyclic action of compressive (Fig. 2d), bending (Fig. 2e) and torsional (Fig. 2e) loads. Using the software of the TIRAtest testing machine, the "load-unload" cycles of the preparations were performed in the interval between the two specified force values. Possible changes in the force at the same time were compensated automatically. During the research, the same cyclic load programs were implemented [7]: an increase in the axial load during the time $\boldsymbol{\tau}_{\text {in }}$ to the occurrence of the maximum force $\mathbf{P}_{\max }$; exposure of the specimen at this load for a time $\boldsymbol{\tau}_{\mathbf{1}}$; reduction of the load during the time $\boldsymbol{\tau}_{\mathbf{r}}$ to the minimum force $\mathbf{P}_{\mathbf{m i n}}$; exposure to the specimen at the minimum load for a time $\tau_{2}$. 
The deformation of the "tibia-plate" systems was carried out with compression at a speed of $5 \mathrm{~mm} / \mathrm{min}$, and with bending and torsion at a speed of $2.5 \mathrm{~mm} / \mathrm{min}$. The holding time of the samples $\boldsymbol{\tau}_{1}$ and $\boldsymbol{\tau}_{\mathbf{2}}$ at $\mathbf{P}=\mathbf{P}_{\max }$ was $1 \ldots 5 \mathrm{~s}$; minimum load $\mathbf{P}_{\min }=10 \mathrm{~N}$.

The maximum number of cycles for each specimen is 100. Individual control specimens were subjected to tests with a number of cycles of up to 1000 . The movements of the fracture points were recorded at the 1st, 2nd, 5th, 10th, 20th, 50th and 100th cycles.

During the test, the following data were recorded:

$\mathbf{\Lambda}_{\mathbf{N}(\max )}-$ is the total (maximum) deformation of the sample at the Nth load cycle at $\mathbf{P}_{\mathbf{1}}=\mathbf{P}_{\mathbf{1 m a x}}$ (compression) Ta $\mathbf{P}_{2}=\mathbf{P}_{2 \max }$ (bend);

$\boldsymbol{\Lambda}_{\mathbf{i}(\min )}-$ is the general (partially irreversible) deformation of the sample on the Nth load cycle at $\mathbf{P}_{\mathbf{1}}=\mathbf{P}_{\mathbf{1} \text { min }}$ (compression) та $\mathbf{P}_{2}=\mathbf{P}_{2}$ min (bend) which does not disappear until the next, $\mathrm{N}+1$ cycle of loading.

$\Gamma_{\mathbf{N}(\max )}$ - is the absolute reciprocal angle of rotation of fracture parts (the angle of twisting of the system) in transverse plane of the bone under the action of the torsional moment $\mathbf{P}_{\mathbf{3}}=\mathbf{P}_{3}$ max

$\boldsymbol{\Gamma}_{\mathbf{N}((\min )}$ - is the general (partially irreversible) angle of rotation on the Nth load cycle at $\mathbf{P}_{\mathbf{3}}=\mathbf{P}_{3}$ min which does not disappear until the next, $\mathrm{N}+1$ st load cycle.

After tests, the characteristics of the cyclic creep process were determined:

$\Lambda_{\mathrm{c}}=\boldsymbol{\Lambda}_{\mathrm{N}(\max )}-\boldsymbol{\Lambda}_{1(\max )}$ - absolute creep deformation as the difference between the movements at the $\mathrm{i}$-th and the first load cycles at $\mathbf{P}_{\mathbf{1}}=\mathbf{P}_{1 \text { max }}$ at compression and $\mathbf{P}_{\mathbf{2}}=\mathbf{P}_{\mathbf{2} \text { max }}$ at bending;

$\Lambda_{\mathrm{H}}=\boldsymbol{\Lambda}_{\mathrm{N}(\min )}-\boldsymbol{\Lambda}_{1(\min )}$ - growth of irreversible displacements as a difference between the movements on the Nth and the first load cycles at $\mathbf{P}_{1}=\mathbf{P}_{1}$ min at compression and $\mathbf{P}_{\mathbf{2}}=\mathbf{P}_{2}$ min at bending;

$\Gamma_{c}=\Gamma_{i(\max )}-\Gamma_{1(\max )}-$ absolute angular deformation of creep as the difference between the rotation angles on the Nth and the first load cycles at $\mathbf{P}_{\mathbf{3}}=\mathbf{P}_{\mathbf{3} \max }$;

$\Gamma_{\mathrm{H}}=\Gamma_{\mathrm{i}(\min )}-\Gamma_{1(\min )}-$ growth of irreversible rotation angles as the difference between the rotation angles on the $\mathrm{N}$ th and the first load cycles at $\mathbf{P}_{\mathbf{3}}=\mathbf{P}_{3}$ min.

As indicators characterizing the deformation properties of the "tibia-plate" system, the selected specific deformations are chosen, defined as the ratio of absolute strain values to the maximum load on each cycle $\mathbf{P}_{\max }$.

$\lambda_{\mathbf{C}}=\Lambda_{\mathbf{C}} / \mathbf{P}_{\max }$ - the cyclic creep deformations are given as the ratio of absolute creep deformation to the maximum load on each cycle;

$\lambda_{\mathbf{H}}=\Lambda_{\mathbf{H}} / \mathbf{P}_{\max }-$ irreversible deformations are given as the ratio of irreversible deformations to the maximum load on each cycle;

$\bar{\gamma}_{C}=\Gamma_{C} /\left(P_{3 \max } \cdot \mathbf{e}_{3}\right)$ - the rotation angles are given as the ratio of the absolute angular deformation of creep to the maximum torsional moment on each cycle (Fig. 4c).

The results of measurements of the total displacements $\boldsymbol{\Lambda}$ of the fracture points and angles of rotation $\boldsymbol{\Gamma}$ remote from the plate at the moment of the action of the maximum $\mathbf{P}_{\max }$ and minimum $\mathbf{P}_{\min }$ loads are given in Table. 5. During the tests, the loads were: $\mathbf{P}_{1 \max }=100 \mathrm{~N}, \mathbf{P}_{\mathbf{P}_{1 \min }}=10 \mathrm{~N}$ (compression), $\mathbf{P}_{2 \max }=20 \mathrm{~N}, \mathbf{P}_{2 \min }=5 \mathrm{~N}$ (bend) and $\mathbf{P}_{3 \max }=$ $10 \mathrm{~N}, \mathbf{P}_{3 \min }=1 \mathrm{~N}$ (torsion).

Fig. 7a-c shows creep processes in the form of changes in the distances between the points of the fracture removed from the plates. Fig. $7 d$ shows the processes of accumulation of irreversible displacements of these points during compression, bending and torsion.

Table 5

Deformations of fractures of the tibia with fixation by plates $2 \mathrm{M}, 3 \mathrm{M}$ and $4 \mathrm{M}$ during compression, bending and torsion under the action of cyclic loading

\begin{tabular}{|c|c|c|c|c|c|c|}
\hline \multirow{2}{*}{$\begin{array}{c}\text { Cycle } \\
\text { number, } \mathbf{N}\end{array}$} & \multicolumn{3}{|c|}{ Deformations at the maximum load cycle } & \multicolumn{3}{|c|}{ Deformations with a minimum load cycle } \\
\hline & $\begin{array}{c}\text { compression, } \\
\Lambda_{\mathrm{C}}, \mathbf{M M}\end{array}$ & $\begin{array}{c}\text { bend, } \\
\Lambda_{\mathrm{C}}, \mathbf{M M}\end{array}$ & $\begin{array}{c}\text { torsion, } \\
\Gamma_{\mathrm{C}},{ }^{0} \\
\end{array}$ & $\begin{array}{c}\text { comression, } \\
\Lambda_{\mathrm{H}}, \mathrm{MM} \\
\end{array}$ & $\begin{array}{c}\text { bend, } \\
\Lambda_{\mathrm{H}}, \mathbf{M M}\end{array}$ & $\begin{array}{c}\text { torsion, } \\
\Gamma_{\mathrm{H}},{ }^{0}\end{array}$ \\
\hline \multicolumn{7}{|c|}{ Plate 2M } \\
\hline 50 & 0.181 & 0.048 & 0.177 & 0.126 & 0.060 & 0.053 \\
\hline 100 & 0.212 & 0.054 & 0.200 & 0.138 & 0.071 & 0.072 \\
\hline \multicolumn{7}{|c|}{ Plate 3M } \\
\hline 50 & 0.196 & 0.054 & 0.208 & 0.147 & 0.087 & 0.094 \\
\hline 100 & 0.233 & 0.062 & 0.238 & 0.160 & 0.098 & 0.107 \\
\hline \multicolumn{7}{|c|}{ Plate $4 M$} \\
\hline 50 & 0.111 & 0.034 & 0.042 & 0.053 & 0.026 & 0.016 \\
\hline 100 & 0.134 & 0.040 & 0.064 & 0.070 & 0.040 & 0.042 \\
\hline
\end{tabular}




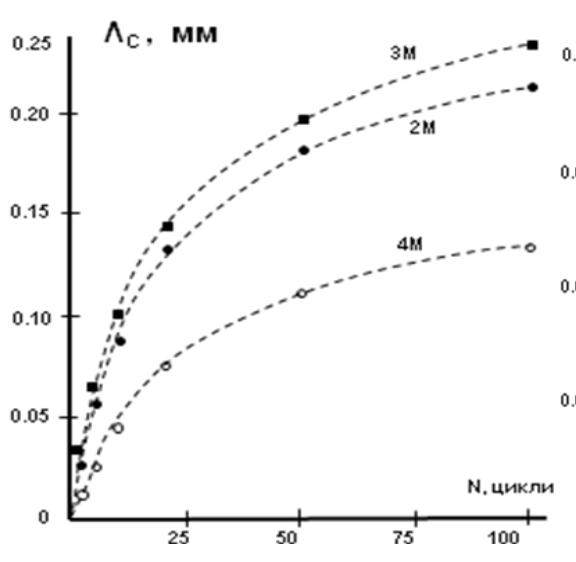

$a$

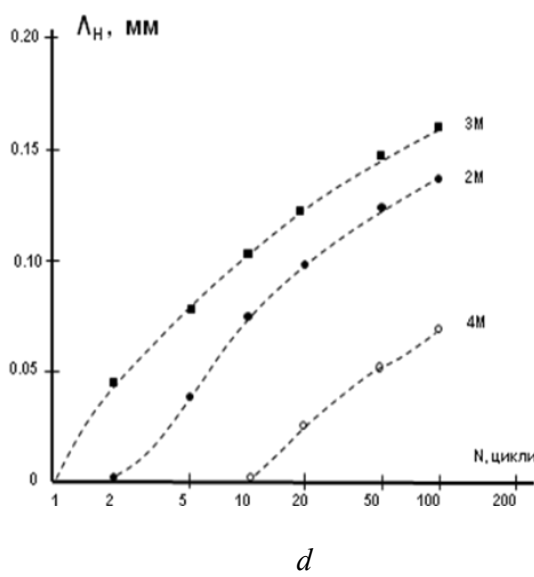

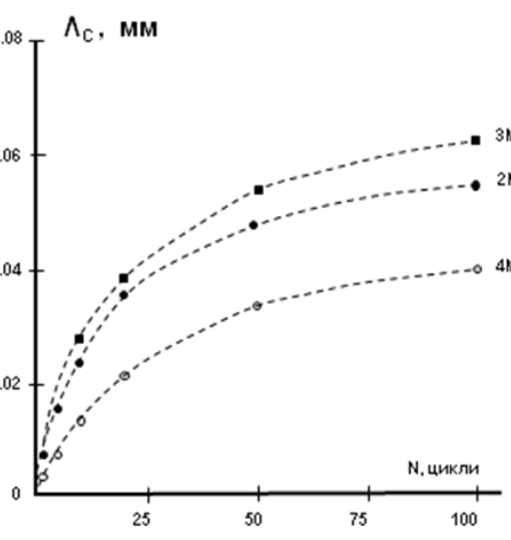

b
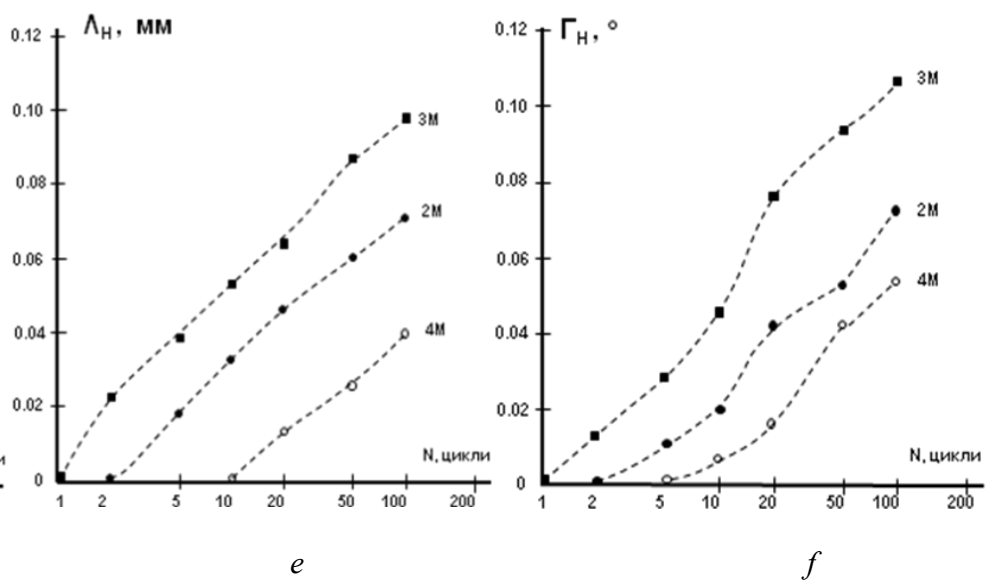

Fig. 7. The development of creep deformations $(a-c)$ and irreversible deformations $(d-f)$ in fractures of the tibia fixed by plates $2 \mathrm{M}, 3 \mathrm{M}$ and $4 \mathrm{M}$ under the action of a cyclic load under compression $(a, d)$, bending $(b, e)$ and torsion $(c, f)$

It is established that small creep strains and irreversible deformations for all kinds of loading arise in fractures fixed by the $4 \mathrm{M}$ plate. The movement that occurred between the 50th and 100th cycles of the load in a fracture fixed by the $4 \mathrm{M}$ plate is $1.6 \ldots 1.7$ times smaller than when fixing with $2 \mathrm{M}$ and $3 \mathrm{M}$ plates, and irreversible movements are less in $2.0 \ldots$ 2.3 times.

\section{Conclusions}

1. In determining the deformation properties of osteosynthesis systems, it is not enough to use the general deformations of the "bone-fixation" system as a whole, but it is necessary to take into account the mutual displacements of the most dangerous points of the fracture region.

2. In fractures fixed by the investigated plates, the displacement occurs not only in the direction of application of the load, but also in transverse directions. When assessing movements in the region of fractures, it is necessary to take into account all the components of displacements, and not just the movement in the direction of the action of the external load.

3. The X-shaped medal titanium plate has the advantage over most of the measured characteristics. The systems fixed by this plate have the largest values of permissible forces both in compression and in bending and torsion. The compressive forces that violate the fixation by these plates are not less than $750 \mathrm{~N}$. The fixation systems with X-shaped medal titanium plates have the smallest creep strains and minimal irreversible deformations for all kinds of load. 


\title{
Деформаційні характеристики систем фіксації переломів великогомілкових кісток
}

\author{
М.С. Шидловський, М.М. Димань, Т.М. Омельченко \\ Анотація. Досліджено характеристики жорсткості та розраховані допустимі навантаження засобів фіксації при \\ переломах дистального епіметафіза великогомілкових кісток. Вивчено процеси розвитку взаємних зміщень точок перелому \\ під дією довготривалих ииклічних навантажень. Металоостеосинтез був виконаний за допомогою різних типів медіальних \\ та латеральних пластин з кутовою стабільністю та блокованих пластин для фіксації складних переломів у дистальному \\ відділі ВГК. Випробування проведені під дією реальних фізіологічних навантажень стиску, згину та кручення, включаючи \\ ииклічні режими навантажень.
}

Ключові слова: остеосинтез, великогомілкова кістка, накісткові пластини, жорсткість фіксаиії переломів, міцність фіксаиії переломів, стабільність фіксачії переломів

\section{Деформационные характеристики систем фиксации переломов большеберцовых костей}

\author{
Н.С. Шидловский, М.М. Дымань, Т.Н. Омельченко
}

\begin{abstract}
Аннотация. Исследованы характеристики жесткости и рассчитаны допустимые нагрузки средств фиксации при переломах дистального эпиметафиза большебериовых костей. Изучены проиессы развития взаимных смещений точек перелома под действием длительных ииклических нагрузок. Металоостеосинтез был выполнен с помощью различных типов медиальных и латеральных пластин с угловой стабильностью и блокированных пластин для фиксации сложных переломов 8 дистальном отделе ВГК. Испытания проведены под действием реальных физиологических нагрузок сжатия, изгиба и кручения, включая цииклические режимы нагрузок.
\end{abstract}

Ключевые слова: остеосинтез, большебериовая кость, накостные пластины, жесткость фиксации переломов, прочность фиксачии переломов, стабильность фиксации переломов.

References

1. Бур'янов О. А., Кваша В. П., Шидловський М. С., Скобенко С. О., Соболевський Ю. Л., Лакша А. М., Омельченко Т. М., Головчак А. В.. Біомеханічне обгрунтування малоінвазивних технологій лікування при переломах проксимального епіметафізу великогомілкової кістки (клініко-експериментальне дослідження) // Травма. - 2014. - Т. 15, № 1. - С. 9-14.

2. Mandi D.M., Belin R.P., Banks J., Barrett B. (Apr 2012). "Pilon fractures”. Clinics in podiatric medicine and surgery. 29 (2): 243-78.

3. Liporace Frank A., Yoon Richard S. (August 2012). "Decisions and Staging Leading to Definitive Open Management of Pilon Fractures". Journal of Orthopaedic Trauma. 26 (8): 488-498.

4. Crist B.D., Khazzam M., Murtha Y.M., Della Rocca G.J. (Oct 2011). "Pilon fractures: advances in surgical management". The Journal of the American Academy of Orthopaedic Surgeons. 19 (10): 612-22.

5. Шидловський М.С., Омельченко Т.М., Димань М.М., Федорчук М.П. Методика визначення деформаційних характеристик систем фіксації переломів великогомілкових кісток // Матеріали всеукраїнської науково-технічної конференції молодих вчених та студентів «Інновації молоді-машинобудуванню», “КПІ” 2017, Київ. - С. 56-59.

6. Шидловський М.С., Омельченко Т.М., Димань М.М. Деформаційні характеристики систем фіксації переломів великогомілкових кісток // XVIII Міжнародна науково-технічна конференція "Прогресивна техніка, технологія та інженерна освіта", 29 червня - 1 липня 2017 року. Київ, - С. 64-66.

7. Експериментальні дослідження засобів остеосинтезу. Кол. авторів / За ред. Шидловського М.С., Лакши А.М., - К.: Ленвіт, 2017. - 277 c.

8. Zelle BA, Bhandari M, Espiritu M, et al. Treatment of distal tibia fractures without articular involvement: a systematic review of 1125 fractures. J Orthop Trauma. 2006;20:76-9. [PubMed]

9. Шидловський М.С., Лакша А.М., Шпак Д.Ю. Уніфікація характеристик деформування в біомеханічних дослідженнях систем остеосинтезу // Літопис травматології та ортопедії. - № 1-2/2013 (25-26). - С.113-117.

10. Патент на корисну модель № 117085 Спосіб визначення зміщення уламків кісток в місцях переломів Шидловський М.С., Заховайко О.П., Димань М.М. Зареєстровано 12.06.2017 р., Бюл. № 11, 2017.

11. Jaarsma RL, van Kampen A. Rotational malalignment after fractures of the femur. J Bone Joint Surg Br. 2004;86:1100-4. [PubMed]

12. Ricci WM, Bellabarba C, Lewis R, et al. Angular malalignment after intramedullary nailing of femoral shaft fractures. J Orthop Trauma. 2001;15:90-5. [PubMed] 